\title{
Physicochemical properties and antioxidant activity of two varieties of apple cultivated in different areas in Morocco
}

\author{
Driss Ousaaid ${ }^{1}$, , Ismail Mansouri ${ }^{2}$, Hassan Laaroussi ${ }^{1}$, Badiaa Lyoussi ${ }^{1}$, and Ilham El Arabi ${ }^{1}$ \\ ${ }^{1}$ Laboratory of Physiology, Pharmacology and Environmental Health, Faculty of Sciences Dhar El Mahraz, \\ P.O.Box 1796 Atlas, Sidi Mohmad Ben Abdellah University, Fez 30000, Morocco \\ ${ }^{2}$ Laboratory of Functional Ecology and Environment. Faculty of Sciences and Technology P.O.Box 2202 \\ Emmouzer road, Sidi Mohamed Ben Abdellah University, Fez, Morocco
}

\begin{abstract}
This study aimed to assess the effect of climate on the organoleptic qualities and phytochemical properties of two varieties of apple (Golden delicious (GD) and Red delicious (RD)) collected from different regions in Morocco. These two varieties of apple were examined for their bioactive compounds composition and antioxidant activity (in juices and different extracts). For physicochemical parameters, the highest acidity was observed in Golden delicious collected from station 1, which was the juiciest sample. Bioactive substances content was dependent on variety and station, while the highest polyphenol content was observed in Golden delicious collected from station $2(135.41 \pm 6.66 \mathrm{mg} \mathrm{GAE} / 100 \mathrm{~mL}$ of juice) and most top flavonoid content was observed in Red delicious collected from station 1 ( $7.43 \pm 0.13 \mathrm{mg} Q \mathrm{QE} / 100 \mathrm{~mL}$ of juice). Furthermore, Red delicious collected from station 2 was the most effective in chelating the radical DPPH (IC50\% $=0.92 \pm 0.01 \mu \mathrm{L}$ of juice), and Red delicious collected from station 1 has the highest total antioxidant activity $(2.47 \pm 0.02 \mathrm{mg}$ AAE/100 mL of juice). The present work showed that the significant diversity in the different studied parameters of the apple cultivars was closely linked with the characteristics of the station, such as geography and climate.
\end{abstract}

Keywords: Golden delicious; red delicious; apple juice; antioxidant activity; polyphenols; flavonoids.

\section{Introduction}

The importance of fruits and their byproducts for human health cannot be overstated. Fruits are considered an essential part of the daily diet and are on high demand because they ensure a balanced diet ${ }^{1}$. Fruits are an inexhaustible source of bioactive constituents ${ }^{2,3}$. Apple serves as a source of different dietary phytonutrients, which possess many pharmacological properties such as antioxidant, antimicrobial, anti-inflammatory, antidiabetic ${ }^{3-5}$.

The daily consumption of apples can play a role in decreasing the risk of different chronic diseases such as cardiovascular disease, cancer and diabetes ${ }^{7-9}$.

Apples are one of the best sources of bioactive compounds ${ }^{10}$. Several studies correlated the bioactive compounds with health-protective activities 2,4-6,11. In the last decades, bioactive compounds earned remarkable attention for their biological activies ${ }^{12}$.

Apples are comprised of several biologically active substances, such as carbohydrates, fiber, vitamins, organic fruit acids, hydroxycinnamic acids, flavonols and anthocyanins ${ }^{13}$.
However, geographical conditions influence the content of some of these bioactive substances content in fruits. In Morocco, the apple crops constitute an important source of income for the Moroccan populations in mountainous areas. Geographical localization of Morocco offers a complete range of Mediterranean bio-climates favoring the development and fruiting of different apple varieties ${ }^{14}$. The apple tree currently occupies an area of about 63000 hectares and ranks as the second among the cultivated rosacea, after the almond tree, according to statistical forecasts reported by Sellika ${ }^{15}$. Products based on apple are numerous and diversified, and they include juice and vinegar. The transformation of apples, unfortunately, remains weak or even absent in Morocco ${ }^{16}$.

This research aimed to assess the proximate physicochemical properties, the antioxidant activity of two varieties of apple cultivated in different areas in Morocco as well as the possible impact of pedoclimatic conditions on bioactive components composition of fruits. 


\section{Materials and methods}

\subsection{Plant material and harvest location}

The plant material was composed of apple fruits of two varieties, Golden delicious and Red delicious; there were collected in October 2019 from different regions in Morocco (station 1: Imilchil, station 2: Ait ayach and station 3: Emmouzzer). The climatic and geolocalisation data are presented in Table 1.

Table 1. Characteristics of sampling sites.

\begin{tabular}{|c|c|c|c|}
\hline Climate data & Station 1 & Station 2 & Station 3 \\
\hline Latitude & $3^{\circ} 3^{\prime} 8.594 \mathrm{~N}$ & $32^{\circ} 41^{\prime} 23.124 \mathrm{~N}$ & $33^{\circ} 44^{\prime} 0.24 \mathrm{~N}$ \\
\hline Longitude & $5^{\circ} 46^{\prime} 9.105 \mathrm{~W}$ & $4^{\circ} 54^{\prime} 29.33 \mathrm{~W}$ & $5^{\circ} 0^{\prime} 37.8 \mathrm{~W}$ \\
\hline Altitude & 2138 & 1516 & 1317 \\
\hline Rainfall mm/ year $^{\text {Annual temperature }}{ }^{\circ} \mathbf{C}$ & 474 & 263 & 612 \\
\hline Bioclimatic stage & 11 & 15.20 & 13.5 \\
\hline
\end{tabular}

\subsection{Preparation of extracts and juices}

The extraction process was performed with two solvents as follows: ethanol $70 \%$, methanol $80 \%$ with sonication for $30 \mathrm{~min}$. The solid to liquid report was 1:10. The obtained extracts were filtered through filter paper and then were analyzed ${ }^{17}$.

For the preparation of juice, the fruits were washed in distilled water and separately blended using a Moulinex blender. The juices were filtered through filter paper and conserved before the analysis. Different samples of juice were named as follows: S1GD: Station 1 Golden delicious, S1RD: station 1 Red delicious, S2GD: station 2 Golden delicious, S2RD: Station 2 Red delicious, S3GD: Station 3 Golden delicious, S3RD: Station 3 Red delicious.

\subsection{Physicochemical properties}

The $\mathrm{pH}$ of juices of different apple varieties was measured by a pH meter (OHAUS ST2100 F). Electric conductivity was measured using a conductivity meter (CD20 Conductivity meter) and was expressed as microsiemens per centimeter $(\mu \mathrm{S} / \mathrm{cm})^{16}$. The total acidity was determined titrimetrically according to the French standard ${ }^{18}$. Brix and density were measured using a refractometer.

\subsection{Phytochemical screening}

\subsubsection{Total polyphenols and flavonoids contents}

The total phenolic content (TPC) was estimated according to the colorimetric method as reported by Singleton and Rossi. ${ }^{19}$ using Folin-Ciocalteu reagent, with some modifications. Briefly, $200 \mu \mathrm{L}$ of juice or extract was mixed with $1 \mathrm{~mL}$ of Folin-Ciocalteau $(0.2 \mathrm{~N})$ reagent and $800 \mu \mathrm{L}$ of sodium carbonate solution. After 2 hours of incubation, the absorbance of the mixture was measured at $760 \mathrm{~nm}$. The results were expressed as mg of gallic acid equivalent per $g$ of fruit and $\mathrm{mg}$ of gallic acid equivalent per $100 \mathrm{~mL}$ for the juice. The total flavonoids (TFC) content was performed using the aluminum trichloride's method described by Kong et al. ${ }^{20}$. Briefly, $200 \mu \mathrm{L}$ of juice or extract was mixed with $300 \mu \mathrm{L}$ sodium nitrite,
$300 \mu \mathrm{L}$ of $\mathrm{AlCl}_{3}$ and $600 \mu \mathrm{L}$ of sodium acetate. Results were expressed as $\mathrm{mg}$ of quercetin equivalent per $\mathrm{g}$ for fruit and as $\mathrm{mg}$ of quercetin per $100 \mathrm{~mL}$ for the juice. Tests were carried out in triplicates.

\subsection{Antioxidant activity}

\subsubsection{DPPH radical scavenging assay}

The DPPH radical scavenging assay was used to examine the antioxidant activity of different extracts and juices. The radical scavenging activity was measured as previously described by Hogg and Russell ${ }^{21}$. The antioxidant capacity of the various extracts and juices studied were interpreted from their IC50. The value of IC50 was expressed in $\mathrm{mg} /$ $\mathrm{mL}$ for different extracts and $\mu \mathrm{L} / \mathrm{mL}$ for juice.

\subsubsection{Total antioxidant capacity}

To evaluate the antioxidant capacity (TAC) of the extracts and juices, the phosphomolybdenum method was used as described by Zengin et al. ${ }^{22}$. The antioxidant capacity of different extracts and juices was evaluated as ascorbic acid equivalents (mg $\mathrm{AAE} / 100 \mathrm{~g}$ of fruit and $\mathrm{mg} \mathrm{AAE} / 100 \mathrm{~mL}$ of juice, respectively).

\subsection{Statistical analysis}

Statistical analysis was carried out by one-way ANOVA through the Past 3 program to determine the significance $(\mathrm{P}<0,05)$. Correlations between the characterizing parameters of samples were achieved by the Pearson correlation coefficient $(r)$ at a significance level of $99 \%(\mathrm{P}<0,05)$. The results were also subjected to a multivariate analysis (principal component analysis).

\section{Results and Discussion}

Physicochemical analyses of juices are summarized in Table 2. The $\mathrm{pH}$ which was recorded in different samples ranged between $3.31 \pm 0.01$ and $4.05 \pm 0.01$; it was slightly acidic, especially in S1GD. Electrical conductivity values ranged between $221.67 \pm 2.51$ and $241.33 \pm 6.42 \mu \mathrm{S} / \mathrm{cm}$ for $\mathrm{S} 2 \mathrm{GD}$ and S1GD, 
respectively. Titratable acidity (TA) content (expressed as $\mathrm{g}$ of malic acid per $100 \mathrm{~mL}$ of juice) varied from $0.48 \pm 0.133$ (S2GD) to $1.82 \pm 0.13$ (S1GD). Concerning the juiciness, the S1GD sample had the highest juiciness value with $67.5 \mathrm{~mL} / 100 \mathrm{~g}$, whilst, the lowest juiciness was established in sample S3RD. The results of this study indicate that the density of all samples ranged between 1.1257 (S3GD) and 1.1297 (S1RD). The values of ${ }^{\circ}$ Brix varies within 16.2 (S3GD) and 16.65 (S1RD).

The obtained results for $\mathrm{pH}$ are comparable to those documented for some fruits such as orange, kiwi fruit and apple ${ }^{23}$, which ranged from 3.23 to 4.22 . Similar findings have been published for the apple in
Poland, Tunisia and China respectively ${ }^{24-26}$. The results of TA from this study were higher than those documented by Boudabous et al. ${ }^{24}$ but similar to those reported previous studies ${ }^{23,26}$. Acidity is one of the elements used to assess fruits quality ${ }^{27}$, and it gives the sour taste due to the presence of malic acid 27. The results of juiciness from this study were in agreement with those reported by Piagentini and Pirovani (2017) ${ }^{28}$. The release of juice and moisture content has an impact on juiciness ${ }^{28}$.

The results indicate that the climate of each station impacts the physicochemical properties of apple varieties studied.

Table 2. Physicochemical parameters of juice samples.

\begin{tabular}{|c|c|c|c|c|c|c|c|}
\hline Station & $\begin{array}{c}\text { Apple } \\
\text { variety }\end{array}$ & pH & $\begin{array}{c}\text { Electrical } \\
\text { conductivity } \\
\mathbf{\mu S} / \mathbf{c m}\end{array}$ & $\begin{array}{c}\text { Titratable } \\
\text { acidity \% }\end{array}$ & $\begin{array}{c}\text { Juiciness } \\
\mathbf{m L / 1 0 0} \\
\mathbf{f w}\end{array}$ & Density & ${ }^{\circ} \mathbf{B r i x}$ \\
\hline \multirow{2}{*}{$\mathbf{S 1}$} & GD & $3.31 \pm 0.01$ & $241.33 \pm 6.42$ & $1.82 \pm 0.13$ & 67.5 & 1.1271 & 16.36 \\
\hline & RD & $4.01 \pm 0.015$ & $230.66 \pm 6.43$ & $0.86 \pm 0.145$ & 61.76 & 1.1297 & 16.65 \\
\hline \multirow{2}{*}{$\mathbf{S 2}$} & GD & $4.03 \pm 0.02$ & $221.67 \pm 2.51$ & $0.48 \pm 0.133$ & 58.82 & 1.1269 & 16.33 \\
\hline & RD & $4.05 \pm 0.01$ & $225 \pm 6.55$ & $0.67 \pm 0.136$ & 66.37 & 1.1283 & 16.49 \\
\hline \multirow{2}{*}{$\mathbf{S 3}$} & GD & $4.1 \pm 0.01$ & $223.34 \pm 9.01$ & $0.68 \pm 0.144$ & 60 & 1.1257 & 16.2 \\
\hline & RD & $3.86 \pm 0.015$ & $237.35 \pm 1.52$ & $0.60 \pm 0.04$ & 53 & 1.1266 & 16.3 \\
\hline
\end{tabular}

S1GD: Station 1 Golden delicious, S1RD: Station 1 Red delicious.

S2GD: Station 2 Golden delicious, S2RD: Station 2 Red delicious.

S3GD: Station 3 Golden delicious, S3RD: Station 3 Red delicious.

fw: fresh weight

The results of the bioactive compounds, namely, polyphenolic compounds and flavonoids, are illustrated in Table 3 . The values vary according to varieties and the stations from which the varieties were collected. The highest content of phenolic compounds was $135.41 \pm 6.66$ and $115.91 \pm 3.16 \mathrm{mg}$ GAE/ $100 \mathrm{~mL}$ of juice established in sample S2GD for Golden delicious and S1RD for Red delicious respectively. The results for TPC in various sample extracts from different stations are presented in Table 3. Their quantity varied within the range of $7.16 \pm 0.72$ to $3.5 \pm 0.3 \mathrm{mg} \mathrm{AGE} / \mathrm{g}$ fw for the Golden delicious and $7.89 \pm 0.28$ to $3.88 \pm 0.02 \mathrm{mg} \mathrm{AGE} / \mathrm{g} \mathrm{fw}$ for the Red delicious. The obtained results are in agreement with previous reports ${ }^{29-31}$. The differences among varieties regarding the TPC could be due to the variation in geographic origin, climatic conditions, technical itineraries, maturity stages, conditions of storage and influence of cultivar ${ }^{30,32,33}$.

Total flavonoids content of our analyzed juices varies between $6.76 \pm 0.02 \mathrm{mg} \mathrm{QE} / 100 \mathrm{~mL}$ and $3.10 \pm 0.02 \mathrm{mg} \mathrm{QE} / 100 \mathrm{~mL}$ from $\mathrm{S} 1 \mathrm{GD}$ and S3GD, respectively. In analyzing both varieties, the Golden delicious of station 2 and Red delicious of station 1 accumulated the highest content of total phenolic substances. In addition, both varieties of station 1 accumulated the highest content of flavonoids. The sharp decrease can explain the fluctuation of flavonoids content in flavonoids during the fruit development ${ }^{34}$. Other factors such as agricultural practices or storage condition can also change the bioactive components of apple and therefore their antioxidant potential.

The total antioxidant activity and the ability of the studied samples to scavenge free radicals DPPH were commonly used to determine the antioxidant potential of various samples.

Total antioxidant capacity of studied samples varied from $2.47 \pm 0.02 \mathrm{mg} \mathrm{QE} / 100 \mathrm{~mL}$ to $1.93 \pm 0.30 \mathrm{mg}$ $\mathrm{QE} / 100 \mathrm{~mL}$ of juice. The sample S1RD has the highest value of total antioxidant capacity, while the sample S1GD has the lowest value. Concerning the different extracts, the highest antioxidant capacity was registered in S2RD ethanol extract, with a value of $7.28 \pm 0.28 \mathrm{mg}$ GAE/ $\mathrm{g}$ fw. While the sample S3GD methanol extract has the lowest antioxidant capacity $(1.13 \pm 0.07 \mathrm{mgGAE} / \mathrm{g} \mathrm{fw})$. The results obtained from this study are lower than those obtained by Drogoudi et al. ${ }^{35}$.

Regarding free radical scavenging activity (DPPH) of different samples, on the one hand, The IC50 DPPH of juices varies within $1.9 \pm 0.11 \mu \mathrm{L}$ (S3RD) and $0.92 \pm 0.01 \mu \mathrm{L}(\mathrm{S} 2 \mathrm{RD})$. On the other hand, the 
IC50\% DPPH of different extracts varied from $2.46 \pm 0.05 \mathrm{mg}$ (S3RDEE) to $0.75 \pm 0.4 \mathrm{mg}$ (S1GDEE). These results indicate that the different samples have potential antioxidant activity. The different climate conditions could explain the difference in the antioxidant activity from one station to another. Apple trees adopted to the adverse pedoclimatic conditions by producing secondary metabolites, which involved in their protection during its development ${ }^{36}$. In addition, bioactive compounds content of apples depends on the cultivars, storage conditions, and stage of maturity of fruits $^{33}$.

Table 3. Total phenolic content, total flavonoids content and antioxidant activity of different juices and extracts.

\begin{tabular}{|c|c|c|c|c|c|c|}
\hline Station & \multicolumn{2}{|c|}{ Sample } & $\begin{array}{c}\text { TFC } \\
\text { mg GAE/ } 100 \text { mL for } \\
\text { juice } \\
\text { mg GAE/g for } \\
\text { extract }\end{array}$ & $\begin{array}{c}\text { TFC } \\
\text { mg QE/ } 100 \mathrm{~mL} \text { for } \\
\text { juice } \\
\text { mg QE/ } 100 \mathrm{~g} \text { for } \\
\text { extract }\end{array}$ & $\begin{array}{c}\text { TAC } \\
\text { mg AAE/ } 100 \mathrm{~mL} \text { for } \\
\text { juice } \\
\text { mg AAE/ } 100 \mathrm{~g} \text { for } \\
\text { extract }\end{array}$ & $\begin{array}{c}\text { DPPH } \\
\text { IC50\% }\end{array}$ \\
\hline \multirow{6}{*}{ S1 } & \multirow{3}{*}{ GD } & Juice & $81.16 \pm 4.41$ & $6.76 \pm 0.02$ & $1.93 \pm 0.306$ & $1.46 \pm 0.19$ \\
\hline & & $\mathrm{EE}$ & $7.16 \pm 0.72$ & $1.4 \pm 0.23$ & $6.01 \pm 0.555$ & $0.75 \pm 0.43$ \\
\hline & & $\mathrm{ME}$ & $7.6 \pm 0.41$ & $0.5 \pm 0.22$ & $3.6 \pm 0.517$ & $2.43 \pm 0.97$ \\
\hline & \multirow{3}{*}{$\mathrm{RD}$} & Juice & $115.91 \pm 3.16$ & $7.43 \pm 0.13$ & $2.47 \pm 0.026$ & $1.82 \pm 0.02$ \\
\hline & & $\mathrm{EE}$ & $5.15 \pm 1.12$ & $1.24 \pm 0.46$ & $5.42 \pm 0.613$ & $1.30 \pm 0.01$ \\
\hline & & $\mathrm{ME}$ & $7.01 \pm 0.72$ & $7.03 \pm 0.71$ & $2.68 \pm 0.210$ & $1.23 \pm 0.11$ \\
\hline \multirow{6}{*}{$\mathbf{S 2}$} & \multirow{3}{*}{ GD } & Juice & $135.41 \pm 6.66$ & $5.07 \pm 0.09$ & $2.06 \pm 0.090$ & $1.13 \pm 0.22$ \\
\hline & & $\mathrm{EE}$ & $3.5 \pm 0.30$ & $0.55 \pm 0.23$ & $3.12 \pm 0.306$ & $1.99 \pm 0.11$ \\
\hline & & $\mathrm{ME}$ & $3.82 \pm 0.45$ & $2.29 \pm 0.17$ & $2.29 \pm 0.249$ & $2.04 \pm 0.50$ \\
\hline & \multirow{3}{*}{$\mathrm{RD}$} & Juice & $107.34 \pm 4.08$ & $3.91 \pm 0.04$ & $2.36 \pm 0.067$ & $0.92 \pm 0.01$ \\
\hline & & $\mathrm{EE}$ & $7.89 \pm 0.28$ & $0.43 \pm 0.11$ & $7.28 \pm 0.280$ & $0.99 \pm 0.08$ \\
\hline & & $\mathrm{ME}$ & $7.61 \pm 0.57$ & $1.17 \pm 0.90$ & $2.98 \pm 0.090$ & $1.77 \pm 0.05$ \\
\hline \multirow{6}{*}{ S3 } & \multirow{3}{*}{ GD } & Juice & $98.5 \pm 7.41$ & $3.10 \pm 0.02$ & $2.37 \pm 0.028$ & $1.22 \pm 0.07$ \\
\hline & & $\mathrm{EE}$ & $4.53 \pm 0.24$ & $0.30 \pm 0.02$ & $5.46 \pm 0.190$ & $2.17 \pm 0.14$ \\
\hline & & $\mathrm{ME}$ & $5.17 \pm 0.2$ & $1.48 \pm 0.23$ & $1.13 \pm 0.070$ & $1.81 \pm 0.09$ \\
\hline & \multirow{3}{*}{$\mathrm{RD}$} & Juice & $94.91 \pm 3.66$ & $4.91 \pm 0.11$ & $2.11 \pm 0.009$ & $1.9 \pm 0.11$ \\
\hline & & $\mathrm{EE}$ & $3.88 \pm 0.02$ & $0.55 \pm 0.20$ & $5.63 \pm 0.081$ & $2.46 \pm 0.05$ \\
\hline & & $\mathrm{ME}$ & $5.43 \pm 0.08$ & $3.56 \pm 0.46$ & $2.06 \pm 0.0503$ & $1.6 \pm 0.80$ \\
\hline
\end{tabular}

EE: Ethanol extract; ME: Methanol extract

TPC: Total Phenolic Content; TFC: Total Flavonoids Content; TAC: Total Antioxidant Capacity.

To better distinguish among the different samples studied in the present work, the principal component PCA was performed as a tool to explore the links among variables and similarities between samples studied ${ }^{37}$. Two principal components were extracted in the PCA model of all samples analyzed (Figure 1). The two primary components (PCs) explained an accumulative variance of $71.875 \%$. 


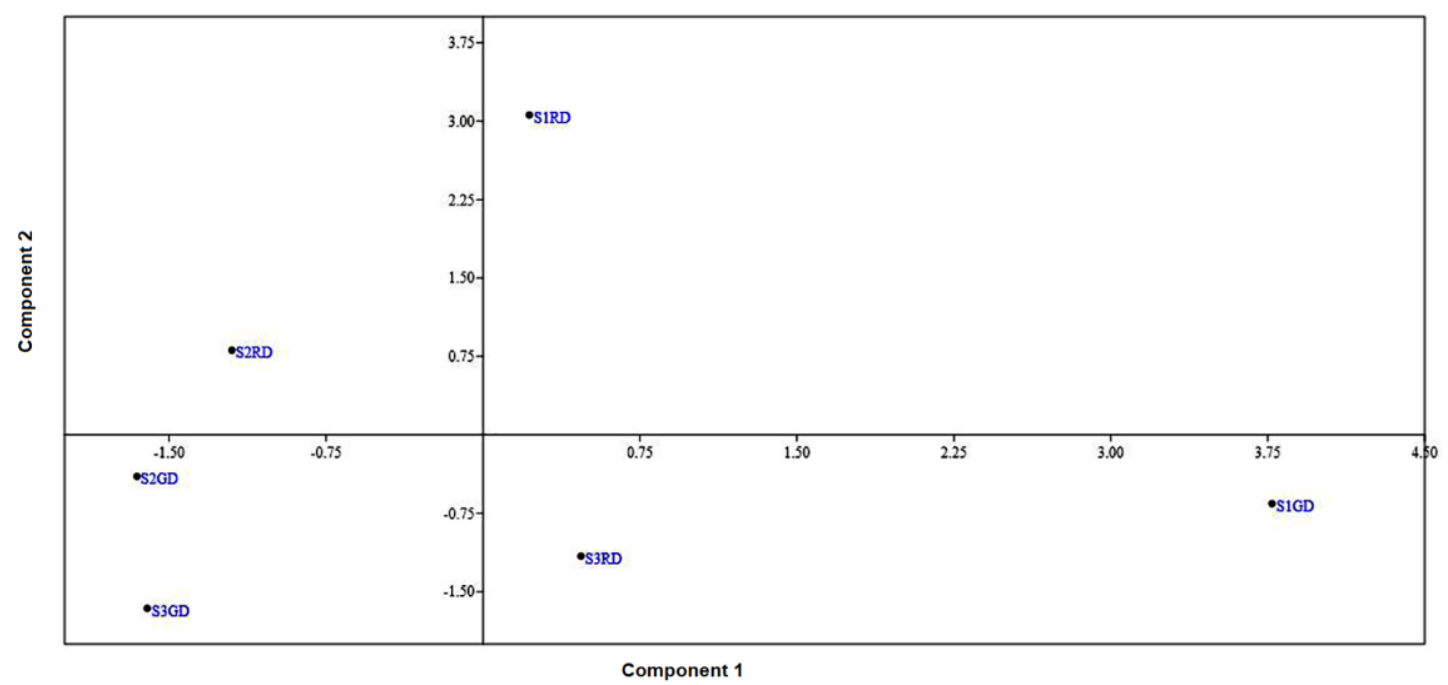

Figure 1. Projection of different samples studied and variable on the factorial plane formed by the first two principal components

The first component explained $42.467 \%$ and represented in its positive part: S1GD, S2RD and S3RD, while the S2RD, S2GD and S3GD were dominating in the negative part.

The second principal component explained $29.408 \%$ of the given results and represented mainly the S1RD and S2RD in the positive part, while the S1GD, S2GD, S3 GD and S3RD in the negative part. Good discrimination was made among the cultivars under investigation, which were discriminated by the second component. The samples S1RD and S2RD were in the positive part of component 2, and S2GD, S3GD, S3RD, S1GD were in the negative part of the same component. Their homogeneity characterizes the S1RD and S2RD in term of phenolic compounds, which implicated a positive correlation with the total antioxidant activity and a negative correlation with IC50\%DPPH. The S1GD was distant from all the other samples studied as a result of its high $\mathrm{pH}$, electrical conductivity, titratable acidity and juiciness. According to the results obtained from PCA, it can be inferred that the distribution of different varieties studied correlated with the station and the variety.

A positive correlation was found between total phenolic compounds and overall antioxidant activity in juice and negatively correlated with IC50\%DPPH ( $r=0.26299$ and -0.27477 , respectively) (Table 4).

The bioactive compounds have a remarkable contribution in the antioxidant activity of different varieties of apple as previously reported by previous studies 28,35 .

Table 4. Pearson correlation coefficients between phytochemical parameters and antioxidant activities of different juices.

\begin{tabular}{|c|c|c|c|c|c|c|c|c|c|c|}
\hline & pH & EC & TA & Juiciness & ${ }^{\circ}$ Brix & Density & TPC & TFC & TAC & $\begin{array}{c}\text { IC50\%DPP } \\
\text { H }\end{array}$ \\
\hline pH & & $\begin{array}{c}0.03365 \\
5\end{array}$ & $\begin{array}{c}0.009170 \\
6\end{array}$ & 0.44083 & $\begin{array}{c}0.8792 \\
7\end{array}$ & 0.86349 & 0.14447 & $\begin{array}{c}0.2807 \\
4\end{array}$ & $\begin{array}{c}0.09413 \\
3\end{array}$ & 0.61654 \\
\hline EC & -0.84622 & & 0.10216 & 0.90523 & $\begin{array}{c}0.8979 \\
2\end{array}$ & 0.9149 & $\begin{array}{c}0.09098 \\
8\end{array}$ & $\begin{array}{c}0.2244 \\
6\end{array}$ & 0.30824 & 0.14665 \\
\hline $\mathbf{T A}$ & -0.92076 & 0.72624 & & 0.17193 & $\begin{array}{c}0.8750 \\
8\end{array}$ & 0.89435 & 0.14084 & $\begin{array}{c}0.2521 \\
6\end{array}$ & 0.35218 & 0.76086 \\
\hline Juiciness & -39302 & $\begin{array}{c}0.06326 \\
5\end{array}$ & 0.63904 & & $\begin{array}{c}0.4638 \\
5\end{array}$ & 0.47135 & 0.66292 & $\begin{array}{c}0.6757 \\
8\end{array}$ & 0.96273 & 0.32156 \\
\hline${ }^{\circ}$ Brix & $\begin{array}{c}0.08065 \\
9\end{array}$ & $\begin{array}{c}0.06816 \\
2\end{array}$ & 0.083471 & 0.37501 & & $\begin{array}{c}0.00248 \\
9\end{array}$ & 0.59697 & $\begin{array}{c}0.1719 \\
5\end{array}$ & 0.35241 & 0.69148 \\
\hline Density & $\begin{array}{c}0.09126 \\
3\end{array}$ & $\begin{array}{c}0.05679 \\
4\end{array}$ & 0.070547 & 0.36921 & $\begin{array}{c}0.9998 \\
7\end{array}$ & & 0.57812 & $\begin{array}{c}0.1772 \\
1\end{array}$ & 0.35104 & 0.70117 \\
\hline TPC & 0.67111 & -0.7424 & -0.67554 & -0.22871 & $\begin{array}{c}0.2756 \\
7\end{array}$ & 0.28933 & & $\begin{array}{c}0.9685 \\
1\end{array}$ & 0.61461 & 0.59821 \\
\hline TFC & -0.52879 & 0.58311 & 0.55579 & 0.21968 & $\begin{array}{c}0.6390 \\
1\end{array}$ & 0.63901 & $\begin{array}{c}- \\
0.02099\end{array}$ & & 0.71452 & 0.21299 \\
\hline TAA & 0.73777 & -0.5038 & -0.4655 & $\begin{array}{c}0.02485 \\
3\end{array}$ & $\begin{array}{c}0.4653 \\
1\end{array}$ & 0.46647 & 0.26299 & $\begin{array}{c}- \\
0.1927 \\
1\end{array}$ & & 0.93433 \\
\hline $\begin{array}{c}\text { ICA50\% } \% \text { DPP } \\
\text { H }\end{array}$ & -0.26161 & 0.66847 & 0.16081 & -0.49199 & $\begin{array}{c}0.2087 \\
1\end{array}$ & 0.20197 & -0.27477 & $\begin{array}{c}0.5948 \\
2\end{array}$ & $\begin{array}{c}- \\
0.04381\end{array}$ & \\
\hline
\end{tabular}




\section{Conclusion}

Physicochemical parameters and antioxidant activity of two apple varieties collected in different areas in Morocco are compared. The content of bioactive compounds depends strictly on the variety of apple. The results revealed that Golden delicious of station 2 (S2GD) was the richest in phenolic content among all the other samples studied. Also, geographical apple crops location had a remarkable effect on the content of bioactive compounds of apple fruits. We conclude that Golden delicious and Red delicious of mountainous regions are potential candidates to be inexhaustible sources of flavonoids and phenolic compounds. These apple varieties can be a basic product for the manufacturing of many by-products with nutritional values.

\section{References}

1- M. Wacker. Common Nutrition and Health Issues. Nutritional and Health Aspects of Food in Western Europe; Eds.; Nutritional\&Health Aspect-Traditional\&Ethnic Food; Academic Press, 2020, 159-171.

https://doi.org/10.1016/B978-0-12-8131718.00009-3.

2- D. A. A. Hyson. A Comprehensive Review of Apples and Apple Components and Their Relationship to Human Health. Advances in Nutrition, 2011, 2 (5), 408-420.

3- K. L. Johnston, M. N. Clifford, L. M. Morgan. Possible Role for Apple Juice Phenolic Compounds in the Acute Modification of Glucose Tolerance and Gastrointestinal Hormone Secretion in Humans. Journal of the Science of Food and Agriculture, 2002, 82 (15), 1800-1805.

4- A. Eisner, P. Ramachandran, C. Cabalbag, D. Metti, P. Shamloufard, M. Kern, M. Y. Hong,

S. Hooshmand. Effects of Dried Apple Consumption on Body Composition, Serum Lipid Profile, Glucose Regulation, and

Inflammatory Markers in Overweight and Obese Children. Journal of Medicinal Food, 2019, 23 (3), 242-249. https://doi.org/10.1089/jmf.2019.0044.

5- T. Zou, B. Wang, S. Li, Y. Liu, J. You. Dietary Apple Polyphenols Promote Fat Browning in High-Fat Diet-Induced Obese Mice through Activation of Adenosine MonophosphateActivated Protein Kinase $\alpha$. Journal of the Science of Food and Agriculture, 2020, 100 (6), 2389-2398. https://doi.org/10.1002/jsfa.10248.

6- Y. Tamura, S. Tomiya, J. Takegaki, K. Kouzaki, A. Tsutaki, K. Nakazato. Apple Polyphenols Induce Browning of White Adipose Tissue. The Journal of Nutritional Biochemistry, 2020, 77, 108299. https://doi.org/10.1016/j.jnutbio.2019.108299.

7- F. B. Hu. Plant-Based Foods and Prevention of Cardiovascular Disease: An Overview. The
American Journal of Clinical Nutrition, 2003, 78 (3), 544S-551S.

8- F. J. He, C. A. Nowson, M. Lucas, G. A. MacGregor. Increased Consumption of Fruit and Vegetables Is Related to a Reduced Risk of Coronary Heart Disease: Meta-Analysis of Cohort Studies. Journal of Human Hypertension, 2007, 21 (9), 717-728. https://doi.org/10.1038/sj.jhh.1002212.

9- E. Riboli, T. Norat. Epidemiologic Evidence of the Protective Effect of Fruit and Vegetables on Cancer Risk. The American Journal of Clinical Nutrition, 2003, 78 (3), 559S-569S.

10-J. Oszmiański, S. Lachowicz, H. Gamsjäger. Phytochemical Analysis by Liquid Chromatography of Ten Old Apple Varieties Grown in Austria and Their Antioxidative Activity. European Food Research and Technology, 2020, 246 (3), 437-448.

11-Y. Li, L. Mei, Y. Niu, Y. Sun, H. Huang, Q. Li, X. Kong, L. Liu, Z. Li, Q. Mei. Low Molecular Weight Apple Polysaccharides Induced Cell Cycle Arrest in Colorectal Tumor. Nutrition and Cancer, 2012, 64 (3), 439-463.

12-A. E. Nicácio, C. A. Rodrigues, I. C. S. F. Jardim, J. V. Visentainer, L. Maldaner. Modified QuEChERS Method for Phenolic Compounds Determination in Mustard Greens (Brassica Juncea) Using UHPLC-MS/MS. Arabian Journal of Chemistry, 2020, 13 (3), 4681-4690. https://doi.org/10.1016/j.arabjc.2019.10.012.

13-E. N. Jensen, T. Buch-Andersen, G. Ravn-Haren, L. O. Dragsted. Mini-Review: The Effects of Apples on Plasma Cholesterol Levels and Cardiovascular Risk-a Review of the Evidence. The Journal of Horticultural Science and Biotechnology, 2009, 84 (6), 34-41.

14-M. Rhanem. Etude Climatique En Moyenne Montagne Méditerranéenne : Le Cas de La Localité de Midelt Dans Le Haut Bassin Versant de La Moulouya (Maroc) Pour Des Fins BioÉcologiques. Quaderni di Botanica ambientale e applicata, 2010, 21, 165-187.

15- I. E. Sellika, N. Faysse, N. Perspectives de Production et de Commercialisation de La Pomme Au Maroc à l'horizon 2025. Alternatives Rurales, 2015, 3.

16- D. Ousaaid, I. Mansouri, M. Rochdi, B. Lyoussi, I. El Arabi. Etude Des Paramètres PhysicoChimiques et de l'activité Antioxydante de Trois Vinaigres de Cidre Traditionnels Issus de Trois Variétés de Pomme de La Région de Midelt Au Maroc. ElWahat pour les Recherches et les Etudes, 2017, 10 (1), 37-50.

17-D. Ousaaid, I. Mansouri, H. Laaroussi,

A. ElGhouizi, B. Lyoussi, I. ElArabi. Phytochemical Content and Antioxidant Activity of Flesh Fruits Rosa Canina Extracts Collected from Ait Ayach Midelt. Indian Journal of Agricultural Research, 2020. https://doi.org/10.18805/IJARe.A-494. 
18-NF V05-101, Détermination de La Teneur En Acidité Volatile in Fruits, Légumes et Produits Dérivés. 1974.

19- V. L. Singleton, R. Orthofer, R. M. LamuelaRaventós. [14] Analysis of Total Phenols and Other Oxidation Substrates and Antioxidants by Means of Folin-Ciocalteu Reagent. Methods in Enzymology, 1999, 299, 152-178.

20-K. W. Kong, S. Mat-Junit, N. Aminudin, A. Ismail, A. Abdul-Aziz. Antioxidant Activities and Polyphenolics from the Shoots of Barringtonia Racemosa (L.) Spreng in a Polar to Apolar Medium System. Food Chemistry, 2012, 134 (1), 324-332.

21-J. S. Hogg, D. H. Lohmann, K. E. Russell. The Kinetics of Reaction of 2, 2-Diphenyl-1Picrylhydrazyl with Phenols. Canadian Journal of Chemistry, 1961, 39 (8), 1588-1594.

22-G. Zengin, T. Arkan, A. Aktumsek, G. O. Guler, Y. S. Cakmak. A Study on Antioxidant Capacities and Fatty Acid Compositions of Two Daphne Species from Turkey: New Sources of Antioxidants and Essential Fatty Acids. Journal of Food Biochemistry, 2013, 37 (6), 646-653.

23-A. Leahu, C. Damian, M. Oroian, S. Ropciuc. Physico-Chemical Parameters of Fruit JuicesEvolution during Storage. Lucrari StiintificeSeria Zootehnie, 2013, 59, 213-217.

24-M. Boudabous, I. Ben Marzouk, N. Marzougui, B. Lechiheb, L. Ben Yahia, A. Ferchichi. Physicochemical Characterization of the Local Apple Cultivar'Douce de Djerba'compared with Introduced Cultivars in Tunisia. In International symposium on Medicinal and Aromatic PlantsSIPAM 2012 997, 2012, 117-128.

25-B. Lata. Relationship between Apple Peel and the Whole Fruit Antioxidant Content: Year and Cultivar Variation. Journal of Agricultural and Food Chemistry, 2007, 55 (3), 663-671.

26-Y. Tian, L. Sun, Y. Yang, X. Gou, P. Niu, Y. Guo. Changes in the Physicochemical Properties, Aromas and Polyphenols of Not from Concentrate (NFC) Apple Juice during Production. CyTA-Journal of Food, 2018, 16 (1), 755-764.

27-S. F. Hagen, G. I. A. Borge, G. B. Bengtsson, W. Bilger, A. Berge, K. Haffner, K. A. Solhaug. Phenolic Contents and Other Health and Sensory Related Properties of Apple Fruit (Malus Domestica Borkh., Cv. Aroma): Effect of Postharvest UV-B Irradiation. Postharvest Biology and Technology, 2007, 45 (1), 1-10.
28-A. M. Piagentini, M. E. Pirovani. Total Phenolics Content, Antioxidant Capacity, Physicochemical Attributes, and Browning Susceptibility of Different Apple Cultivars for Minimal Processing. International Journal of Fruit Science, 2017, 17 (1), 102-116.

29-S. Guyot, R. Symoneaux, J. M. Le Quéré, R. Bauduin. es Polyphénols de La Pomme Aux Cidres: Diversité Variétale et Procédés, Facteurs Clé de La Modulation Des Saveurs et Des Couleurs. Innovations Agronomiques, 2014, 42, 105-123.

30-E. Mehinagic, E. Bourles, F. Jourjon. Composés Des Fruits d'intérêt Nutritionnel : Impact Des Procédés de Transformation Sur Les Polyphénols. Revue Suisse de Viticulture, Arboriculture et Horticulture, 2011, 43 (6), 364368.

31-Y. Xu, M. Fan, J. Ran, T. Zhang, H. Sun, M. Dong, Z. Zhang, H. Zheng. Variation in Phenolic Compounds and Antioxidant Activity in Apple Seeds of Seven Cultivars. Saudi Journal of Biological Sciences, 2016, 23 (3), 379-388.

32-M. J. Amiot, M. Tacchini, S. Aubert, J. Nicolas. Phenolic Composition and Browning Susceptibility of Various Apple Cultivars at Maturity. Journal of Food Science, 1992, 57 (4), 958-962.

33-M. J. Amiot, M. Tacchini, S. Y. Aubert, W. Oleszek. Influence of Cultivar, Maturity Stage, and Storage Conditions on Phenolic Composition and Enzymic Browning of Pear Fruits. Journal of Agricultural and Food Chemistry, 1995, 43 (5), 1132-1137.

34-C. M. Renard, N. Dupont, P. Guillermin. Concentrations and Characteristics of Procyanidins and Other Phenolics in Apples during Fruit Growth. Phytochemistry, 2007, 68 (8), 1128-1138.

35-P. D. Drogoudi, Z. Michailidis, G. Pantelidis. Peel and Flesh Antioxidant Content and Harvest Quality Characteristics of Seven Apple Cultivars. Scientia Horticulturae, 2008, 115 (2), 149-153.

36-E. M. A. Siqueira, F. R. Rosa, A. M. Fustinoni, L. P. Sant'Ana, S. F. Arruda. Brazilian Savanna Fruits Contain Higher Bioactive Compounds Content and Higher Antioxidant Activity Relative to the Conventional Red Delicious Apple. PloS One, 2013, 8 (8), e72826. https://doi.org/10.1371/journal.pone.0072826.

37-M. Forina, S. Lanteri, C. Armanino. Chemometrics in Food Chemistry. Chemometrics and species identification, 1987, 91-143. 